\title{
Pengembangan konten positif sebagai bagian dari gerakan literasi digital
}

\author{
Detta Rahmawan ${ }^{1}$, Jimi Narotama Mahameruaji ${ }^{2}$, dan Renata Anisa ${ }^{3}$ \\ ${ }^{1,2,3}$ Universitas Padjadjaran, Bandung, Indonesia
}

\begin{abstract}
ABSTRAK
Menjamurnya hoaks, misinformasi, disinformasi, hingga riuhnya konflik terkait isu politik identitas di media digital adalah contoh permasalahan yang coba diatasi oleh gerakan literasi digital di Indonesia. Salah satu strategi gerakan ini adalah dengan mengajak khalayak media, terutama anak muda untuk lebih banyak mengonsumsi, membuat, dan menyebarkan "konten positif". Menariknya, hingga kini masih belum ada kajian yang mendefinisikan dan menggali lebih jauh pandangan serta persepsi anak muda itu sendiri terkait dengan konsep konten positif. Oleh karena itu, melalui penelitian ini, peneliti melakukan penggalian pemahaman konten positif pada anak muda dengan melakukan focus grup discussion kepada total 36 mahasiswa yang tersebar di empat perguruan tinggi negeri di Jawa Barat, yaitu Universitas Padjadjaran, Universitas Pendidikan Indonesia, Institut Pertanian Bogor, dan Universitas Singaperbangsa Karawang. Selain itu wawancara mendalam juga dilakukan kepada lima pakar terkait media digital yang terdiri dari perwakilan pihak akademisi, industri, maupun pemerintahan. Eksplorasi juga dilakukan pada pemberitaan terkait konten positif di media online. Penelitian ini memperlihatkan bahwa ide penyebaran konten positif sebagai bagian dari gerakan literasi digital masih belum dipahami anak muda dengan baik. Selain itu, tidak ada kesepahaman terkait definisi operasional dari konten positif. Informan menyatakan bahwa konten yang bernilai informatif, inspiratif, dan memiliki nilai guna, adalah contoh konten positif. Informan juga memiliki persepsi bahwa konten positif memiliki jumlah dan tingkat popularitas di bawah konten yang bersifat negatif. Mereka juga mengatakan bahwa masih diperlukan berbagai sosialisasi literasi digital dan konten positif agar ide ini dapat diterima dan disebarkan secara lebih luas.
\end{abstract}

Kata-kata Kunci: konten media; konten positif; literasi digital; media digital; media sosial

\section{Proliferation of positive content as part of digital literacy movement}

\begin{abstract}
The proliferation of hoaxes, misinformation, disinformation, and the emergence of conflicts caused by identity politics are examples of problems in the digital media that tried to be tackled by the digital literacy movement, where one of its strategy is to invite young people to consume, spread, and make their own positive content. This study explores how the notion of positive content is perceived by young people by conducting focus group discussion to a total of 36 students spread across four public universities in West Java, namely Universitas Padjadjaran, Universitas Pendidikan Indonesia, Institut Pertanian Bogor, and Universitas Singaperbangsa Karawang. In addition, in-depth interviews were also conducted with five experts consists of representatives from academia, industry and government. This research carried out analysis on news related to positive content in online media. The results of our study show that the idea of spreading positive content as part of the digital literacy movement is still not well understood by young people. In addition, there is no general agreement on the conceptualization of positive content. However, the informants agreed that informative, inspirational content and use value were important factors in evaluating positive content. Informants also have the perception that there is inadequate amount of positive content compared to negative content. Furthermore, the popularity of positive content is also limited. They also said that various forms of socialization on digital literacy and positive content is still needed so that this idea could be accepted and disseminated more widely.
\end{abstract}

Keywords: digital media; digital literacy; media content; positive content; social media

Korespondensi: Detta Rahmawan, S.I.Kom., MA. Universitas Padjadjaran. Jl. Raya Bandung-Sumedang KM 21, Jatinangor 45363 Jawa Barat.Email: detta@unpad.ac.id 


\section{PENDAHULUAN}

Teknologi digital memiliki beragam dampak dalam masyarakat modern. Namun di Indonesia, dampak dari teknologi digital terutama dalam rangka pemberdayaan masyarakat belum terasa signifikan. Pada era digital sekarang ini, seiring dengan kemajuan teknologi komunikasi dan informasi, membuat perkembangan Internet semakin melaju pesat (Kusuma \& Sugandi, 2018). Dampak teknologi digital memiliki beragam dimensi yang saling terkait, dan membutuhkan perhatian tersendiri. Misalnya saja, berbicara mengenai penetrasi Internet dan teknologi digital di Indonesia tentunya tidak dapat dilepaskan dari permasalahan akses. Hadirnya media sosial memungkinkan pengguna untuk saling bertukar informasi tanpa mengenal batas ruang dan waktu (Mendayun \& Sjuchro, 2018). Meskipun penetrasi Internet terus naik tiap tahun, kesenjangan infrastruktur masih sangat terasa, terutama di berbagai wilayah bagian timur Indonesia. Sebagian besar pengakses Internet berada di kota-kota besar seperti Jakarta, Bandung, Yogyakarta, Surabaya, dan kota-kota besar lain di pulau Jawa. Begitu pula dengan industri komunikasi dan media yang hingga kini juga masih sangat terpusat di Jakarta yang menyebabkan potensi pemberdayaan masyarakat lewat teknologi digital masih sangat bersifat Jakarta atau Jawasentris (Jurriëns \& Tapsell, 2017).

Terdapat paradoks yang menarik bahwa meskipun belum memiliki penetrasi Internet yang merata, Indonesia adalah negara yang sangat ramah terhadap beragam teknologi dan aplikasi baru seperti media sosial. Hingga saat ini, terdapat kurang lebih 130 juta pengguna Facebook di Indonesia yang tersebar di berbagai penjuru Indonesia (We Are Social, 2018). Di beberapa tempat terpencil di Indonesia yang bahkan belum memiliki arus listrik yang stabil pun, telah terdapat pengguna Facebook (Ryssdal, 2014). Media sosial lain seperti, Twitter sempat merajai penggunaan media sosial di Jakarta dan Bandung, dimana dua kota ini termasuk dalam kota yang memiliki pengguna Twitter yang sangat aktif di dunia (Semiocast, 2012). Di tahun 2017, Indonesia sempat menjadi salah satu pasar terbesar bagi Instagram (Yosephine, 2017), dan Indonesia juga sudah lama menjadi salah satu pasar potensial bagi pengembangan produk Google seperti YouTube, sehingga bisnis YouTubers dalam konteks pemasaran dan periklanan digital di negara ini menjadi sangat potensial dan menghasilkan perputaran uang dengan jumlah yang besar (Mahameruaji, Puspitasari, Rosfiantika, \& Rahmawan, 2018). Meskipun demikian, pesatnya penetrasi media sosial dan berbagai aplikasi digital lain belum diikuti oleh tingkat kompetensi literasi digital yang mumpuni. Hal ini menjadi krusial untuk diperhatikan lebih lanjut terutama terkait berbagai dampak negatif yang dapat disebabkan oleh teknologi digital, serta bagaimana hingga saat ini pemerintah Indonesia masih belum memiliki rancangan program yang jelas terkait dengan peran strategis beragam teknologi digital bagi pemberdayaan masyarakat dan pengurangan ketimpangan sosial (Wulandari, 2017). Media bertujuan untuk memberi hiburan, dan terkandung fungsi informatif (Saptya, Permana, Puspitasari, \& Indriani, 2018)

Dalam konteks perkembangan teknologi inilah media digital menjadi alternatif sumber informasi bagi banyak pengguna Internet di Indonesia. Informasi tidak lagi menjadi monopoli milik media konvensional arus utama. Media digital membuka lebar keran informasi yang dapat dikatakan tidak memiliki "filter" atau penyaring konten. Dalam keadaan "membanjirnya informasi" ini, pemerintah melalui Kominfo (Kementerian Komunikasi dan Informatika) berinisiatif untuk menjadi regulator konten, dengan membuat payung hukum dalam Peraturan Menteri Komunikasi dan Informatika Republik Indonesia nomor 19 tahun 2014, yang berisikan kewenangan Kominfo dalam menangani situs-situs yang dianggap memiliki muatan konten negatif. Meskipun demikian, pembuatan peraturan hukum ini diprotes oleh berbagai lembaga swadaya masyarakat yang memiliki perhatian pada tata kelola Internet dengan alasan bahwa Kominfo telah gagal mendefinisikan secara spesifik mengenai apa itu konten bermuatan negatif. Peraturan tersebut hanya mencantumkan beberapa kategori konten negatif secara tidak spesifik, yaitu konten berbau pornografi, konten yang melanggar privasi, konten berisi kekerasan, isu SARA (Suku Agama, Ras, dan Antar Golongan) serta konten yang dianggap dapat menimbulkan "keresahan masyarakat secara luas". Selain itu, berbagai wewenang Kominfo dalam melakukan pemblokiran konten juga dianggap dapat memberangus kebebasan 
berekspresi dan iklim demokrasi di Indonesia (detikINET, 2014; ICT Watch, 2014). Kebijakan pemblokiran situs negatif oleh Kominfo ini juga dinilai terlalu mengedepankan aspek moralitas serta tidak melalui mekanisme yang transparan dan proses pengadilan (Hidayat, 2016).

Pada tanggal 2 Oktober 2017, Menteri Komunikasi dan Informatika Rudiantara meluncurkan program gerakan nasional literasi digital dengan nama \#SiBerkreasi. Fokus utama gerakan ini adalah seruan kepada masyarakat luas untuk secara aktif menyebarluaskan konten positif. Upaya ini dianggap sebagai salah satu cara untuk melawan penyebaran berbagai konten negatif di media digital. Gerakan \#SiBerkreasi adalah kolaborasi dari berbagai institusi, baik pemerintah, swasta, beragam komunitas, hingga menjangkau para pegiat literasi digital. \#SiBerkreasi juga dibentuk dalam rangka mmpromosikan gerakan literasi digital kepada masyarakat luas (Biro Humas Kementerian Komunikasi dan Informatika, 2017). Gerakan ini juga dapat dilihat sebagai upaya lain Kominfo dalam mengatasi konten negatif yang beredar secara masif di dunia online selain secara rutin melakukan pemblokiran situs maupun aplikasi.

Gerakan \#SiBerkreasi adalah salah satu inisiatif pemerintah dalam merespons peredaran konten negatif di masyarakat, terutama di kalangan anak muda sebagai pengguna utama media digital yang dianggap semakin meresahkan. Seperti juga telah dijelaskan sebelumnya, salah satu cara krusial yang coba ditawarkan dan dikembangkan terkait penanggulangan konten negatif adalah dengan memperbanyak konten positif. Namun, konseptualisasi dan definisi "konten positif" tidak dipaparkan secara rinci dan detail. Misalnya saja, apa yang dipersepsi oleh pemerintah dan pihak-pihak yang terlibat dalam \#SiBerkreasi mengenai konten positif belum tentu sesuai dengan nilai-nilai dan ekspektasi anak muda. Meskipun demikian, belum ada studi yang juga kemudian mencoba untuk mengonseptualisasi konten positif seperti apa yang harus dikembangkan dalam rangka melawan maraknya peredaran konten negatif. Selain itu, hingga kini masih belum ada penelitian yang mencoba untuk menggali lebih jauh bagaimana pemahaman dan persepsi anak muda terkait apa itu konten positif. Oleh karena itu, penelitian ini mencoba memberikan gambaran terkait pemahaman konten positif oleh anak muda, terutama oleh mahasiswa yang menjadi fokus dalam studi ini. Selain itu peneliti juga bermaksud untuk mencoba mengkaji apakah gerakan pengembangan konten positif ini dapat dianggap relevan oleh anak muda yang menjadi salah satu sasaran utama dalam gerakan literasi digital secara umum. Kajian tentang gerakan literasi digital saat ini tentu relevan dengan keberadaan teknologi media digital di masyarakat dengan segala implikasinya. Berdasarkan hal-hal yang telah dijabarkan di atas maka tujuan penelitian ini adalah untuk mengetahui bagaimana konsep konten positif di media digital dipahami oleh para informan, serta mengeksplorasi lebih detil terkait konten positif seperti apa yang relevan untuk dikembangkan lebih lanjut dalam gerakan literasi digital.

Pengembangan model literasi media kini telah menjadi agenda dari banyak negara di seluruh dunia. Di tahun 2014, UNESCO mengadakan sebuah konferensi besar di Paris yang menekankan urgensi pengembangan berbagai program literasi media terutama dengan perkembangan teknologi komunikasi dan digitalisasi di seluruh dunia. Pertemuan yang mengundang ratusan peserta dari seluruh dunia ini menyimpulkan bahwa diperlukan sebuah bentuk literasi media dan literasi digital yang harus didukung penuh oleh berbagai kebijakan pemerintah, dan dapat menyentuh semua lapisan masyarakat. Konsep dan gerakan literasi media dianggap berperan penting dalam menghasilkan sebuah masyarakat yang mampu berpartisipasi secara aktif dalam beragam sendi kehidupan berwarganegara (UNESCO, 2014).

Konsep literasi digital pertama kali dikemukakan dengan salah satu fokus terkait bagaimana menjadi khalayak yang mampu untuk melakukan pencarian, pengolahan, dan penggunaan berbagai informasi secara online (Gilster, 1997). Kaitan antara literasi digital dan informasi menjadi salah satu fokus utama yang ditekankan dalam berbagai program literasi digital, dan hal ini kemudian dikritik karena kemampuan literasi tidak melulu tertuju pada kaitannya dengan informasi, namun harus lebih luas. Literasi digital juga harus menanamkan kemampuan untuk berpikir kritis dan peka terhadap berbagai fenomena sosiokultural yang ada. Teknologi digital tidak hanya dapat dilihat sebagai instrumen atau 
alat semata, namun juga dapat dilihat sebagai bagian dari kehidupan masyarakat secara luas, dimana teknologi itu akan selalu membentuk dan dibentuk oleh penggunanya (Buckingham, 2015). Literasi digital, terutama bagi anak muda dan orang dewasa juga haruslah dilihat sebagai praktik sosial yang melekat pada perkembangan teknologi, sehingga masyarakat hendaknya menyadari pentingnya konsep dan penerapan literasi digital ketika mereka setiap hari tidak dapat terhindar dari praktik-praktik keseharian yang bersentuhan dengan berbagai teknologi (Livingstone, van Couvering, \& Thumim, 2005).

Pada beberapa negara maju seperti Amerika Serikat, Inggris, hingga Kanada, program literasi media telah terintegrasi dalam kurikulum pendidikan (Chen, 2007; McNulty, 2004). Kebijakan ini berupaya untuk mengenalkan konsep literasi media dan berpikir kritis sedini mungkin, dan hal ini diambil dengan kesadaran bahwa terpaan media memiliki beragam dampak yang harus diperhatikan. Selain lewat pendidikan dasar, pengembangan program literasi media juga telah menjadi perhatian dari beberapa organisasi masyarakat sipil yang bekerja sama dengan lembaga donor dan institusi akademis.

Penggunaan teknologi digital secara produktif sebagai praktik pemberdayaan individu juga menjadi fokus utama dalam berbagai gerakan literasi digital, sehingga beberapa negara misalnya, berinisiatif untuk memasukkan literasi digital pada kurikulum pendidikan formal, seperti dilakukan di Afrika Selatan dan juga sempat dilakukan di Indonesia lewat penerapan mata pelajaran TIK (Teknologi Informasi dan Komunikasi) di kurikulum 2006 sebelum akhirnya mata pelajaran ini tidak lagi berdiri sendiri namun diintegrasikan pada mata pelajaran lain lewat perubahan kurikulum pendidikan di tahun 2013 (Kurnia \& Astuti, 2017b). Selain lewat pendidikan formal, di Indonesia, pasca reformasi dan perkembangan pesat industri media, gerakan literasi media juga mulai berkembang secara luas. Pada tahun 1991, terjadi inisiasi gerakan literasi media pada sebuah acara terkait anak dan televisi di Cipanas, Jawa Barat yang digagas oleh Yayasan Kesejahteraan Anak Indonesia (YKAI) beserta Children's Centre, kemudian diikuti pula oleh Asian Media, Information and Communication Centre (AMIC) Singapura (Rianto, 2013, hal. 193). Sejak saat itu, muncul berbagai gerakan literasi media terutama yang diinisiasi oleh pemerintah maupun perguruan tinggi dengan kegiatan seperti seminar, sosialisasi, kampanye, hingga program pengabdian kepada masyarakat. Meskipun demikian program literasi media yang telah banyak dilakukan masih berorientasi jangka pendek dan sporadis, alih-alih berkelanjutan dan berfokus pada hasil yang bersifat jangka panjang (Poerwaningtias et al., 2013, hal. 14).

Seiring dengan perkembangan teknologi, dengan kondisi gerakan literasi media yang belum mapan dan jauh dari ideal, tantangan terkait gerakan ini juga muncul dari penetrasi beragam teknologi digital di masyarakat. Gerakan literasi media juga mulai tidak hanya berfokus pada media konvensional dan terutama televisi, namun juga pada berbagai media digital baru yang semakin menjadi bagian dari masyarakat luas. Masyarakat Indonesia dalam beberapa tahun belakangan ini dipandang sebagai masyarakat yang cukup terbuka terhadap teknologi-teknologi baru, terutama tentunya yang berkaitan dengan media digital. Apalagi hal ini juga didukung oleh fakta bahwa lebih dari separuh pengguna Internet di Indonesia adalah mereka yang berasal dari kalangan masyarakat urban yang sangat akrab dengan beragam media sosial (APJII, 2017; We Are Social, 2018).

Meskipun demikian upaya untuk pemberdayaan masyarakat, terutama generasi muda terkait media digital masih belum tertata dengan baik. Berbagai program pemberdayaan melalui media digital yang telah berjalan di Indonesia ternyata memiliki masalah serupa seperti gerakan literasi media konvensional sebelumnya. Fokus gerakan masih hanya sebatas program jangka pendek dan bukan program yang dirancang secara hati-hati dan dapat berkelanjutan (Kurnia \& Astuti, 2017a). Wahyudi Djafar, sebagai peneliti dari lembaga Studi dan Advokasi Masyarakat (ELSAM) lewat keterangannya dalam sebuah wawancara di media mengatakan bahwa sudah terlalu lama Kominfo terlalu fokus pada upaya untuk melakukan pemblokiran konten dan mengupayakan solusi dengan pengaturan infrastruktur, alih-alih memfokuskan diri untuk membangun gerakan literasi media yang dapat mengakar kuat pada masyarakat (CNN Indonesia, 2018). 


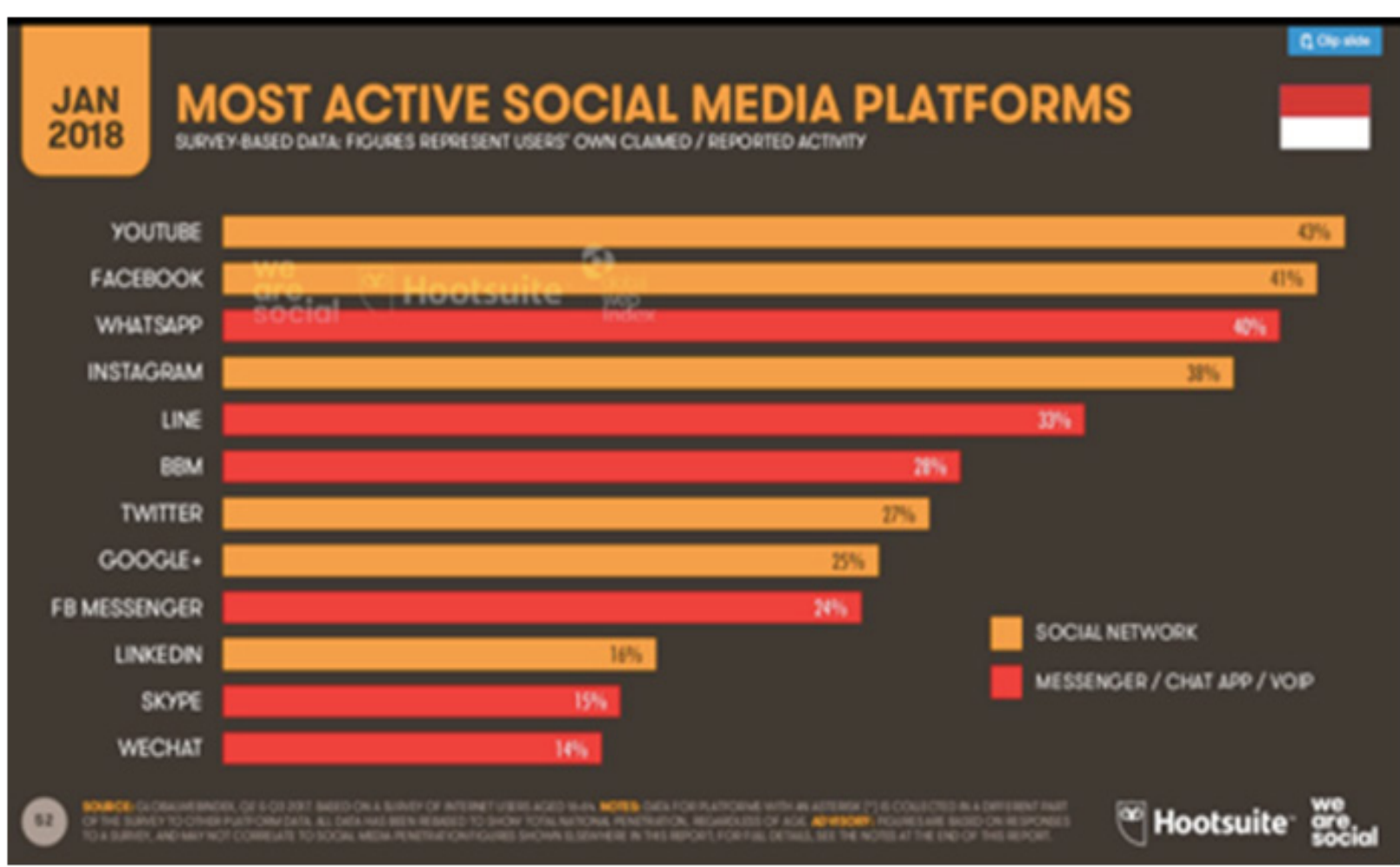

Sumber: We Are Social, 2018

Gambar 1 Data terkait penggunaan media sosial tahun 2018

Permasalahan gerakan literasi digital juga dapat dicermati dari penelitian Japelidi (Jaringan Pegiat Literasi Digital) yang memperlihatkan pola gerakan literasi digital di sembilan kota; Jakarta, Surakarta, Malang, Yogyakarta, Salatiga, Semarang, Bandung, Banjarmasin, dan Bali. Studi ini mengungkapkan terjadinya "kegagapan digital" di masyarakat Indonesia, yang antara lain diperlihatkan oleh "Menyebarnya hoaks dan ujaran kebencian, maraknya cyberbullying, penggunaan media sosial untuk kegiatan terorisme dan radikalisme, dan ketergantungan yang tinggi atau kecanduan pada media digital" (Kurnia \& Astuti, 2017a). Penelitian ini juga dengan tegas menyatakan perlunya kegiatan literasi digital dilakukan secara berjaringan dan berkesinambungan, di mana salah satu peran sentral mengenai pemberdayaan masyarakat terkait media digital seharusnya dapat dilakukan oleh perguruan tinggi. Belum optimalnya gerakan literasi digital tentunya amat disayangkan, di saat beberapa potensi untuk mendapatkan keuntungan lewat media digital sudah semakin besar. Misalnya saja, teknologi media digital dianggap dapat melahirkan entrepreneurship media baru (Conway, 2014), melahirkan anak-anak muda yang dapat memperoleh penghasilan besar dari kanal YouTube mereka (Putri, 2018), maupun ikut serta dalam beragam kegiatan ekonomi digital yang sedang berkembang di Indonesia (Freischlad, 2017).

Dalam perspektif uses and gratification, dikatakan bahwa setiap individu memiliki alasan atau motivasi yang berbeda dalam keputusannya untuk mengonsumsi media. Meskipun demikian, berbagai kajian mengatakan bahwa salah satu keputusan utama yang mendasari seseorang dalam mengonsumsi media, terutama adalah karena mereka mencari suatu konten yang dapat membuat mereka terhibur, senang, dan melupakan sejenak berbagai macam persoalan yang ada dalam hidupnya (eskapisme) atau dengan kata lain konten yang menghibur adalah salah satu jenis konten yang paling digemari manusia (Rubin, 2009). Konten yang menghibur, misalnya seperti film dengan genre komedi yang mampu membuat khalayaknya tertawa terbahak-bahak, film aksi yang menegangkan, ataupun film percintaan yang romantis, dapat dengan mudah kita terima dan kategorikan sebagai konten yang dapat memicu perasaan yang menyenangkan dan membuat kita terhibur.

Meskipun demikian, berbagai riset juga menyadari bahwa keinginan untuk terhibur, 
bukanlah motivasi tunggal yang menjelaskan kegemaran kita dalam mengonsumsi konten hiburan di media. Penjelasan lain yang juga memungkinkan untuk diterima adalah bahwa kita terkadang tidak hanya mencari konten untuk kesenangan dan pemuasan keinginan terkait hiburan (hedonistik) namun kita juga memiliki kemungkinan untuk lebih menyukai dan mencari konten media yang 'bermakna', dan mampu membuat kita 'tergerak', 'tersentuh', dan tidak sekadar terhibur (eudaimonik) (Oliver \& Raney, 2011). Literatur terkait media dan psikologi juga menunjukkan bahwa konten media dapat meningkatkan perasaan kagum, terkesima, dan rasa berterima kasih seseorang. Oleh karena itu, terbuka kemungkinan akan adanya konten media yang digemari oleh khalayaknya karena kebutuhan atau pencarian mereka akan 'makna', 'panggilan hidup' dan 'inspirasi' yang dapat membuat mereka tergugah (Dale, Raney, Janicke, Sanders, \& Oliver, 2017). Logika ini membantu menjelaskan bahwa konten hiburan pun dapat bersifat positif serta menginspirasi khalayaknya untuk tidak sekadar menjadi senang dan terhibur.

Berbagai riset yang telah disebutkan di atas dilakukan secara spesifik meneliti konten film hiburan dan efeknya pada khalayak. Tentu saja perbedaan jenis konten media akan memiliki pengaruh pada khalayak dengan cara yang relatif berbeda. Dalam konteks jurnalistik, dan konten berita, Arianna Huffington, founder dari salah satu media online terbesar di Amerika Serikat The Huffington Post menuliskan gugatannya atas salah satu asumsi yang kokoh tertanam dalam konteks jurnalistik yaitu bahwa berita buruk selalu lebih menjual daripada berita baik atau "if it bleeds, it leads". Ia misalnya, mengutip dari sebuah buku berjudul "Contagious: Why Things Catch On" yang mengatakan bahwa banyak orang lebih mungkin membagikan berita yang mampu memicu perasaan positif dibandingkan dengan perasaan negatif. Ia mengatakan bahwa idenya ini bukan berarti bahwa semua produk jurnalistik yang memang menyelidiki hal yang bersifat negatif seperti ketidakadilan, dan permasalahan sosial di dunia tidak boleh dipublikasikan. Juga bukan berarti bahwa media harus selalu mengatakan bahwa "dunia itu indah, damai, dan semua baik-baik saja". Melainkan ia menyerukan untuk sebisa mungkin membingkai berita, fakta dan cerita tersebut dengan nuansa yang lebih manusiawi, inspiratif, berempati, bermakna dan solutif. Arianna mengatakan bahwa ketika khalayak terus menerus dibombardir dengan berita yang pesimis dan negatif, maka terdapat kemungkinan akan terciptanya khalayak yang lelah, apatis, acuh, dan cenderung untuk menarik diri dari realitas (Huffington, 2015).

Konten media, saat ini bukanlah monopoli milik industri media maupun produk jurnalistik, namun juga milik pengguna biasa yang membuat konten lewat media sosial mereka. Kelahiran berbagai platform media sosial yang mengusung konsep "konten yang dibuat pengguna" (Murthy, 2012) membuat wacana tentang nuansa konten yang tersebar secara online menjadi semakin rumit Salah satunya adalah persoalan tentang hoaks, dan berita palsu yang menjadi topik hangat terutama dalam konteks politik. Pada era media sosial seperti saat ini, konten tidak hanya dikonsumsi dan berhenti pada satu pembaca, namun juga dapat disebarkan oleh si pembaca, kepada jaringannya yang lebih luas.

Dalam konteks ini penyebaran konten tidak lagi bergantung pada si pembuat konten awal (produsen konten media) namun juga oleh para khalayaknya yang kini dapat lebih aktif mengomentari, menyebarkan, bahkan memanipulasi konten media. Hal ini lah yang kemudian menimbulkan persoalan baru karena ternyata konten dengan nuansa negatif, khususnya berita palsu yang negatif ternyata dapat lebih cepat menyebar dibandingkan berita positif. Hal ini disimpulkan oleh sekumpulan peneliti dari MIT lewat sebuah riset yang dilakukan dengan mengamati konten di media sosial Twitter sejak tahun 2006 hingga 2017 (Vosoughi, Roy, \& Aral, 2018). Dengan fakta baru ini, tentu relevansi pengembangan konten positif, dalam konteks perkembangan industri media yang semakin mutakhir menjadi menarik untuk dikaji kembali.

\section{METODE PENELITIAN}

Penelitian ini menggunakan metode studi kasus untuk menjabarkan secara detail dan komprehensif pengembangan konten positif sebagai bagian dari gerakan literasi digital (Creswell, 2007). Studi kasus dipilih karena wacana konten positif adalah sebuah kasus yang baru mulai muncul di tahun 2017, tepatnya dengan diluncurkannya inisiatif Gerakan Nasional Literasi Digital \#SiBerkreasi melalui 
Siaran Pers No. 184/HM/Kominfo/10/2017 (Biro Humas Kementerian Komunikasi dan Informatika, 2017). Fokus pada konten positif sebagai suatu hal yang dianggap dapat membantu gerakan literasi digital di Indonesia memiliki keunikan tersendiri dari segi sosial budaya masyarakat penggunanya. Selain itu, konten positif yang dapat diterima oleh anak muda merupakan sebuah keunikan tersendiri, yang tentunya sangat kontekstual.

Lokasi penelitian ini adalah di Jawa Barat, dengan detail lokasi penelitian yang peneliti pilih adalah di Unpad, dan UPI di Bandung, IPB di Bogor, dan Unsika di Karawang. Pemilihan lokasi dan informan penelitian dilakukan dengan metode Purposive Sampling. Total 36 peserta FGD peneliti pilih dengan kriteria seperti: mahasiswa tingkat akhir, berasal dari bidang ilmu yang memiliki keterkaitan dengan dunia komunikasi (Ilmu Komunikasi, Jurnalistik, Manajemen Komunikasi, Humas, Ilmu Informasi dan Perpustakaan dan Komunikasi Pembangunan) telah diterpa media digital dalam kehidupannya sehari-hari selama lebih dari lima tahun, aktif di media sosial seperti Instagram, Twitter, dan YouTube, aktif menggunakan aplikasi pesan instan seperti WhatsApp dan LINE, rutin mengonsumsi informasi lewat media-media online dan memiliki smartphone yang selalu terkoneksi dengan Internet selama 24 jam.

Semua mahasiswa peserta FGD mengakui bahwa media digital telah menjadi bagian dari kehidupan mereka sehari-hari. Mayoritas dari informan telah memiliki smartphone sendiri sejak SMA. Mereka menggunakan media digital untuk berbagai macam kepentingan mulai dari hiburan, kepentingan kuliah, hingga beragam hal terkait kegiatannya. Hampir semua informan juga mengaku bahwa mereka mulai menyadari bahwa apa yang mereka lakukan secara online, dan berbagai aktivitas mereka di media sosial sebagai hal yang dapat mempengaruhi masa depan mereka secara profesional. Semua mahasiswa Peserta FGD mengakui bahwa media digital telah menjadi bagian dari kehidupan mereka sehari-hari. Mayoritas dari informan peneliti telah memiliki smartphone sendiri sejak SMA. Mereka menggunakan media digital untuk berbagai macam kepentingan mulai dari hiburan, kepentingan kuliah, hingga beragam hal terkait kegiatannya. Hampir semua informan juga mengaku bahwa mereka mulai menyadari bahwa apa yang mereka lakukan secara online, dan berbagai aktivitas mereka di media sosial sebagai hal yang dapat mempengaruhi masa depan mereka secara profesional.

Selain FGD, wawancara mendalam juga dilakukan kepada perwakilan dari pihak akademisi yang mendalami studi media dan anak muda, praktisi media terkait dengan bisnis industri digital, dan perwakilan dari pemerintahan (Kominfo). Wawancara peneliti lakukan terkait dengan pandangan dan pendapat mereka terkait isu konten positif di media digital, literasi digital dan dampak media digital terhadap anak muda. Selain itu, peneliti juga melakukan eksplorasi dari pemberitaan dan data yang tersedia secara publik terkait konten positif di media digital. Semua kutipan yang diambil dari wawancara dituliskan secara anonim untuk melindungi privasi informan.

\section{HASIL DAN PEMBAHASAN}

Menurut hasil dari eksplorasi pemberitaan terkait konten positif yang telah peneliti lakukan, di Indonesia, konsep konten positif lahir bersamaan dengan adanya kekhawatiran terkait banyaknya konten negatif yang beredar di Internet dan media sosial. Dalam salah satu pemberitaan dari Kompas.com misalnya, Rudiantara selaku menteri komunikasi dan Informatika menyatakan kekhawatirannya akan persebaran konten negatif seperti konten bermuatan pornografi, SARA, terorisme, radikalisme, dll, sembari menyatakan keinginannya untuk memenuhi Internet dengan konten yang lebih bermanfaat, memiliki nilai-nilai edukasi dan inspirasi. Ia juga mengemukakan bahwa Indonesia baru memiliki 250.000 situs bermuatan konten positif, dan telah melakukan pemblokiran terhadap 800.000 situs bermuatan konten negatif (Bohang, 2017). Pengembangan dan penyebaran konten positif juga adalah salah satu strategi terkait dengan promosi literasi digital di masyarakat luas. Dengan karakteristik masyarakat yang memiliki tingkat literasi rendah, tentunya diperlukan gerakan-gerakan dari pemerintah untuk memastikan penetrasi Internet dan media sosial yang cukup tinggi dan terus meningkat tidak menyebabkan menjamurnya dampak-dampak yang dinilai negatif dan dapat merugikan masyarakat. Sudut pandang seperti ini adalah sudut pandang terkait media yang sangat 
paternalistik, dimana negara merasa seperti "orang tua" yang berhak untuk "mengarahkan" warga negaranya dalam hal interaksi dengan media.

Konten positif sendiri sebetulnya tidak didefinisikan secara baku oleh Kominfo selaku salah satu pihak yang berkepentingan dalam gerakan literasi digital secara luas. Dari hasil penelusuran peneliti melalui mesin pencari Google, tidak ditemukan adanya upaya Kominfo untuk melakukan definisi "konten positif" secara ilmiah dan sistematis. Asumsi peneliti adalah bahwa konsep ini dianggap sebagai konsep yang bersifat "common sense", sebagai sebuah konsep dimana "semua orang dianggap paham". Tidak adanya definisi baku konten positif memiliki implikasi baha semua pihak dapat memiliki gambaran tentang konten positif menurut pendapatnya sendiri. Hal inilah yang kemudian peneliti klarifikasi lewat diskusi yang peneliti lakukan dengan para mahasiswa yang menjadi informan dalam penelitian ini.

Apakah "positif" memiliki keterkaitan dengan kualitas? Apakah "positif" berarti harus selalu ditujukan untuk masyarakat umum (general audience)? Apakah "positif" berarti sebuah konten yang harus informatif, edukatif, dan menginspirasi? Selain berbagai pertanyaan ini tentunya akan ada pertanyaan terkait siapa atau mekanisme apa yang berhak menentukan sebuah konten bersifat positif di Internet.

Selain dari rujukan pemberitaan dan tinjauan literatur, peneliti melakukan wawancara mendalam terhadap perwakilan dari pihak akademisi, praktisi, dan pemerintahan terkait industri media digital dan anak muda yang peneliti anggap dapat memberikan sumbangan pemikiran terkait konten positif di media digital. Peneliti mewawancarai dosen dan pengamat media digital dari salah satu universitas swasta terkemuka di Jakarta, tiga orang praktisi dengan level manajer yang berkecimpung di industri media digital, dan satu orang perwakilan dari Kementerian Komunikasi dan Informatika. Peneliti juga mengambil beberapa data terkait prariset yang telah dilakukan dalam penelitian sebelumnya dimana peneliti mendapatkan data terkait industri konten media digital dari seorang founder perusahaan Multi-Channel Network, sekaligus influencer yang kerap berkecimpung dalam promosi literasi digital (Rahmawan, Mahameruaji, \& Hafiar, 2017).

Dalam Focus Group Discussion, ketika ditanya mengenai konten yang bersifat negatif, semua peserta memiliki kesepakatan bahwa konten negatif adalah terkait provokasi isu SARA, konten berisi pornografi, hingga ujaran kebencian dan hoaks. Hal ini memperlihatkan bahwaterdapatbeberapakesepahamanmengenai apa itu konten di media digital yang dianggap lebih membawa dampak negatif di masyarakat, wacana tentang hoaks sebagai konten yang saat ini dianggap paling membahayakan juga diamini oleh para informan. Meskipun ketika digali lebih lanjut, terdapat perdebatan terkait konsep-konsep definitif terkait, apa yang dimaksud dengan ujaran kebencian, sejauh mana sebuah konten dengan isu sensitif seperti agama dan politik masih dapat diterima, dll. Keragaman pemikiran, latar belakang sosioreligiusitas dan tingkat keterbukaan pandangan tentunya berperan di sini. Misalnya saja, ketika membicarakan tentang isu "pribumi" yang digunakan oleh Anies Baswedan dalam pidato pertamanya sebagai gubernur DKI Jakarta, terdapat peserta yang melihat bahwa pidato itu secara konseptual bermasalah namun ada juga yang menganggap bahwa isu pribumi sengaja dibesar-besarkan.

Ketika ditanya mengenai konten positif, semua peserta memiliki pendapat berbeda, namun terdapat benang merah dari jawaban mereka yaitu konten positif haruslah memiliki informasi dan nilai guna bagi khalayaknya. Beberapa peserta menambahkan bahwa konten positif yang spesifik bagi anak muda bisa juga berisi tentang pemberdayaan anak muda, apapun bentuknya, namun konten itu harus secara umum "bermanfaat" bagi anak muda sebagai khalayaknya.

"[konten] positif yang memberikan informasi yang informatif, tips and tricks, yang negatif kayak hatespeech, pornografi, hoax (P, 24 tahun)

"[konten] positif itu informasi, konten hiburan, tips and trick, negatifnya pornografi sama hoax" (I, 22 tahun)

"[konten] Positif itu fakta, science, news, hobby and features, motivation. Negative hoax, hatespeech, porn, sama provocative" (Kominfo, 22 tahun)

Para peserta FGD ini juga mengatakan bahwa konten media sosial yang membahas tentang isu sosial dan politik juga penting bagi anak muda, namun terkadang konten tersebut tidak akan dipersepsi secara seragam oleh 
anak muda. Beberapa peserta juga sudah mulai menyadari bahwa konten yang berisikan isu sosial dan politik, terutama yang dimuat oleh media-media online seperti Kompas.com hingga Tirto.id, dapat memiliki muatan yang dapat digunakan untuk menggiring isu publik, dan menurut mereka anak muda seharusnya mampu untuk melihat bagaimana media menunjukkan keberpihakannya terhadap isu-isu tertentu. Hal ini menjadi menarik karena menunjukkan bahwa menurut mereka kemampuan dasar literasi media terkait dengan pemahaman tentang siapa yang membuat media, berbagai dampak konten media, dan kesadaran bahwa konten media selalu merupakan hasil 'konstruksi' adalah salah satu skill yang seharusnya dimiliki oleh anak muda.

Menariknya, ketika diminta untuk menyebutkan beberapa kreator di media digital yang mereka anggap positif, seluruh peserta mengalami sedikit kesulitan dan beberapa mengaku bahwa konsumsi konten positif mereka lebih didominasi oleh konten yang diproduksi oleh kreator non-lokal. Beberapa peserta menambahkan bahwa kreator lokal yang dipandang positif jumlahnya sedikit, namun peserta lain menambahkan bahwa mungkin masalahnya bukan pada jumlah yang sedikit, tapi dari kurangnya exposure terhadap di masyarakat luas. Misalnya saja, salah seorang peserta menambahkan bahwa faktor algoritme di YouTube membuat penggunanya akan mengonsumsi konten yang sejenis dan jarang untuk melihat konten lain, sehingga kemungkinan untuk diterpa kreator lokal mungkin juga berkurang. Beberapa kreator lokal yang mereka anggap memiliki konten positif misalnya adalah Gita Savitri, Raditya Dika, Bayu Skak, Benakribo, Kelas Pagi, Kok Bisa, Watch Dog, Remotivi, Erick Soekamti, Pinter Politik, Asumsi, dll. Kebanyakan dari kreator yang mereka sebutkan ini cukup populer di YouTube meskipun mereka juga memiliki akun di media sosial lain.

Terjadi perdebatan ketika salah seorang peserta mengemukakan perlunya ada pihak yang memiliki otoritas untuk mengatur atau mengontrol konten, misalnya untuk membuat konten yang berisikan isu-isu sensitif terkait SARA. Ia berpendapat harus ada standardisasi dan kontrol terkait isu SARA di media digital yang dibuat oleh pemerintah, namun peserta lain menolakide tersebut karena ia mengkhawatirkan hal itu akan menjadi monopoli pemerintah. Tentunya hal ini dapat dieksplorasi terkait persoalan kendali standardisasi konten. Apakah hal ini memang benar diperlukan? Atau justru dapat menjadi alat kontrol pemerintah yang bersifat represif? Hal ini menunjukkan perlunya diskusi lebih lanjut terkait otoritas pengelolaan konten. Apakah Kominfo berhak untuk menjadi otoritas tersebut? Dan bagaimana situasi demokratisasi dapat terjaga dengan adanya pihak yang menjadi otoritas pengelola konten.

Ketika hasil FGD peneliti diskusikan dengan para narasumber ahli, semua narasumber ahli peneliti setuju bahwa saat ini ada banyak sekali konten bersifat negatif yang mengkhawatirkan mereka. Namun di sisi lain, bagi mereka konten negatif tidak selalu terkait dengan pornografi, SARA, radikalisme, ataupun terorisme, namun juga beragam konten hiburan yang tidak berkualitas dan diproduksi hanya dengan dasar keuntungan tanpa memedulikan adanya dampak dari konten tersebut, dan konten-konten terutama berita yang dibuat tanpa mempedulikan etika komunikasi dan etika jurnalistik. Meskipun narasumber peneliti relatif memilik pendapat yang sama tentang konten apa yang dapat dikategorikan sebagai konten "negatif" tidak demikian halnya dengan konten positif. Narasumber ahli peneliti sepakat bahwa tidak ada definisi yang baku dari konten yang bersifat "positif".

Mereka juga mengaku belum terlalu mengetahuiataumendengarbahwakonten positif ini adalah bagian dari promosi atau gerakan literasi digital yang sedang dilakukan oleh Kominfo. Narasumber peneliti yang bekerja di LINE (salah satu aplikasi pesan instan yang saat ini populer di Indonesia) juga mempertanyakan bahwa apabila pemerintah memang ingin untuk menjangkau anak muda, seharusnya mereka menghubungi pihak LINE untuk mengadakan semacam kerjasama, mengingat saat ini LINE adalah salah satu aplikasi yang paling digemari oleh anak muda. Seorang akademis yang menjadi narasumber peneliti juga berpendapat bahwa selain mempromosikan konten positif, sebetulnya pemerintah masih memiliki pekerjaan rumah besar dalam hal peningkatan literasi media, karena baginya konsep literasi media menjadi persoalan yang lebih urgen dan harus diperhatikan dengan saksama. Konten positif akan meningkat apabila sebagian besar masyarakat menjadi masyarakat yang 
cukup melek media, sehingga mereka akan bisa melakukan penyaringan konten media dengan baik, dan memilik kemampuan untuk membedakan mana konten yang berkualitas dan tidak.

Strategi pengembangan konten positif dan pemberdayaan anak muda mulai menjadi perhatian dari para pemerhati maupun pengggerak literasi media digital. Di Indonesia sendiri, belum banyak lembaga yang secara konsisten melakukan kajian terkait pemberdayaan anak muda terkait penggunaan media digital. Lembaga swadaya masyarakat seperti ICT Watch (Indonesian ICT Partnership Association), dapat dikatakan sebagai contoh lembaga yang sejak lama membahas beragam masalah terkait media digital. Misalnya saja, ICT Watch dalam situsnya yang beralamatkan di http://ictwatch.id memiliki program-program pemberdayaan masyarakat melalui Internet yang berkaitan dengan partisipasi aktif masyarakat dalam proses demokratisasi di Indonesia. ICT Watch memiliki tiga program unggulan yaitu pembuatan film dokumenter mengenai media sosial berjudul "Linimassa", program literasi digital "Internet Sehat" di http://Internetsehat. id dan juga pembuatan sebuah web hosting gratis bagi para organisasi non-profit yang juga berisikan berbagai koleksi buku yang dapat diunduh secara gratis http://kalamkata.org.

Selain ICT Watch, upaya untuk mempopulerkan gerakan literasi digital juga dilakukan oleh Kelas Muda Digital (Kemudi), yang memiliki kelas online dan modul literasi digital dengan fokus pada anak muda. Modul dari Kemudi, selain dapat diunduh secara bebas, juga dapat dipelajari bersama melalui platform KelasKita.com. Platform ini memungkinan para peserta melakukan interaksi langsung dengan para fasilitator. Di tahun 2017, mereka mengatakan bawa kelas online mereka telah diikuti lebih dari 600 orang (Herman, 2017). Modul terkait literasi digital yang dapat diunduh bebas oleh masyarakat luas, video kreatif, hingga berbagai berita terkait literasi digtal juga terus diproduksi oleh Kominfo dan dipublikasikan lewat situs http://literasidigital. id.

Akan tetapi efektivitas berbagai gerakan yang dipaparkan di atas, dan terutama dalam kaitannya dengan pengembangan konten positif dapat dikatakan belum teruji dengan baik. Para informan dalam penelitian peneliti mengakui bahwa gerakan atau promosi literasi media oleh pemerintah dan berbagai pihak yang berkepentingan (Universitas, LSM) masih belum memadai. Begitu juga tentang anjuran pemerintah bagi anak muda untuk mengembangkan dan mempromosikan konten positif di media digital juga masih terlihat belum maksimal, karena faktanya persepsi tentang apa dan seperti apa konten positif akan sangat berbeda. Apalagi untuk membuat konten positif tidak hanya diperlukan keahlian, tapi juga

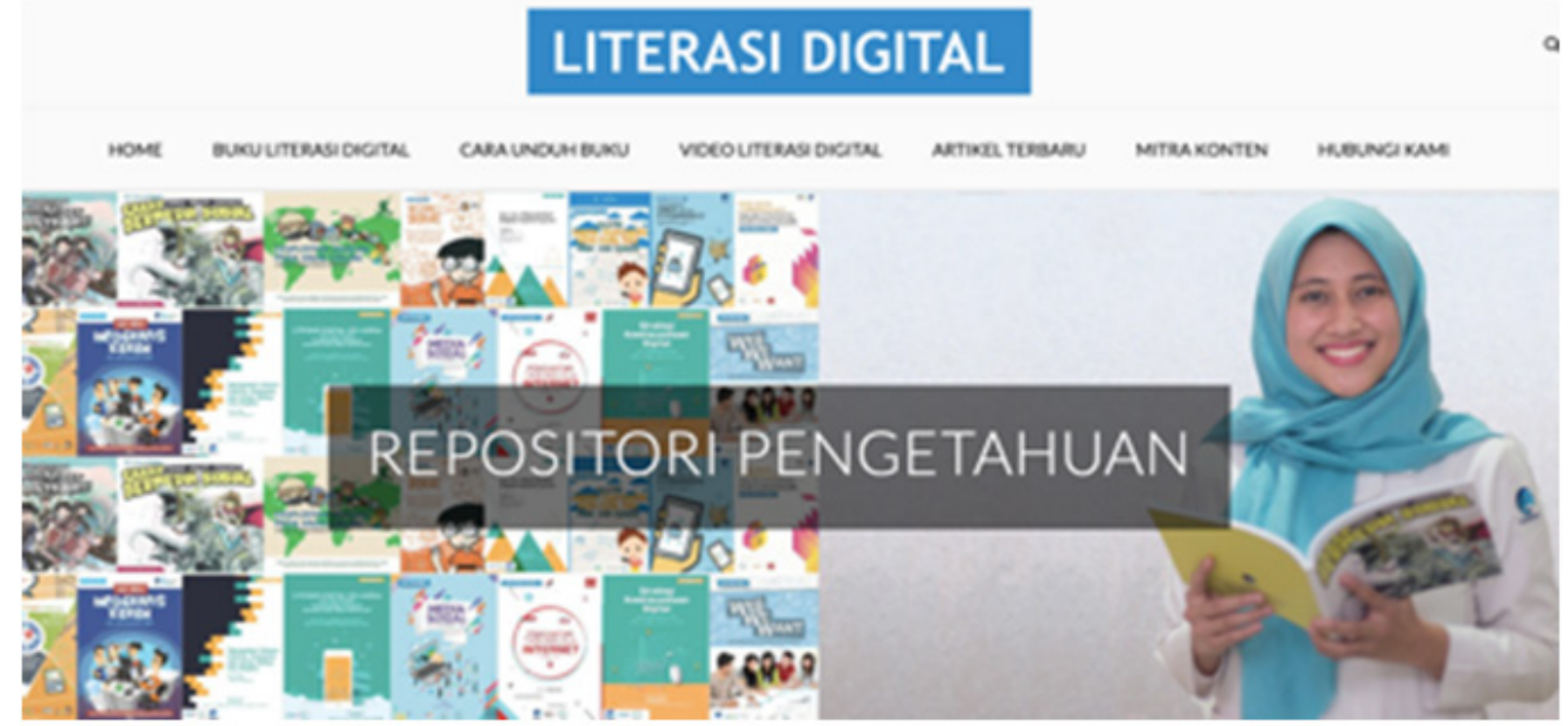

Sumber: Kementerian Komunikasi dan Informatika, 2018

Gambar 2 Situs Repositori Buku terkait Literasi Digital 
motivasi dan faktor terkait keberlangsungan konten, dan insentif bagi para anak muda yang ingin memulai untuk menjadi kreator konten.

Terkait dengan insentif, pembahasan tentang insentif ini menjadi menarik karena banyak peserta yang menyadari bahwa popularitas konten yang positif dianggap kurang jika dibandingkan dengan konten hiburan ataupun konten negatif. Peserta FGD peneliti juga mengakui bahwa kadang kualitas dan popularitas konten positif di media digital masih tertinggal apabila dibandingkan dengan konten-konten yang lain. Misalnya saja, konten positif yang terkait dengan pembahasan mengenai sains dan pendidikan di Indonesia dinilai masih sangat kurang. Hal ini peneliti konfirmasi dengan pemberitaan dan data yang peneliti dapatkan secara publik, seperti dari Social Blade yang, memperlihatkan bahwa dari 250 YouTuber dengan subscriber terbesar di Indonesia, hanya satu YouTubers, yaitu "KokBisa" yang kontennya secara konsisten membahas tentang pendidikan dan sains. Mayoritas YouTubers dengan genre konten yang bersifat hiburan memenuhi komposisi dan konsentrasi dari Top YouTubers di Indonesia (Rahmawan, Mahameruaji, \& Janitra, 2018).

Selain itu, informan peneliti juga mengatakan bahwa perlu ada gerakan bersama antara para kreator, dan berbagai pihak lain yang memiliki kepentingan terkait wacana media digital yang lebih sehat, seperti kolaborasi antara pemerintah, LSM, dan akademisi. Jaringan antar kreator yang memiliki kepedulian terhadap isu-isu sosial juga diperlukan sehingga jaringan ini dapat lebih memfokuskan pada konten positif dan berdampak sosial dan mereka dapat bersinergi dan saling membantu mempromosikan konten mereka. Inisiatif seperti YouTube Creators for Change (https://Kominfo.youtube.com/intl/ $\mathrm{id} / \mathrm{yt} /$ creators-for-change/) juga dipandang positif sebagai salah satu program yang mengedepankan perlunya semakin banyak kreator menggunakan pengaruhnya untuk halhal positif di masyarakat.

\section{SIMPULAN}

Hasil penelitian memperlihatkan bahwa konten positif adalah konsep yang sulit untuk didefinisikan secara operasional. Namun informan sepakat bahwa konten yang informatif, dan memiliki nilai guna, adalah dua faktor penting dalam penilaian terkait konten positif. Informan peneliti juga memiliki persepsi bahwa konten positif memiliki jumlah dan tingkat popularitas di bawah konten yang bersifat negatif. Selain itu, mereka pun mengungkapkan bahwa masih diperlukan berbagai sosialisasi terkait konten positif dan konsep literasi digital secara umum agar ide ini dapat menjadi wacana arus utama di masyarakat.

Beberapa contoh kreator konten yang bersifat positif telah ditemukan dari FGD yang telah dilakukan. Namun tentu saja ranah media digital masih memerlukan banyak konten kreator lain, dan perlu ada jaringan bagi para kreator dan anak muda yang memiliki kepedulian untuk mengembangkan kontenkonten yang dapat bermanfaat bagi anak muda. Penelitian ini tentunya memiliki keterbatasan secara metodologis dan hasil yang ada tidak dapat digeneralisir. Oleh karena itu penelitian selanjutnya dapat dilakukan dengan melakukan penggalian data secara detail terkait konten positif dalam bentuk untuk melihat perspektif lain dari definisi konten positif yang kemudian dapat didiskusikan dengan berbagai pihak yang terkait dengan gerakan literasi digital di Indonesia.

\section{DAFTAR PUSTAKA}

APJII. (2017). Survei penetrasi dan perilaku pengguna Internet Indonesia 2017. Jakarta. Diakses dari https://Kominfo.apjii. or.id/content/read/39/342/Hasil-SurveiPenetrasi-dan-Perilaku-Pengguna-InternetIndonesia-2017.

Biro Humas Kementerian Komunikasi dan Informatika. (2017). Gerakan nasional literasi digital \#SiBerkreasi ajak masyarakat sebar konten positif. Diakses 10 September 2018, dari https://Kominfo. go.id/content/detail/10801/siaran-pers-no184hmKominfo102017-tentang-gerakannasional-literasi-digital-siberkreasiajak-masyarakat-sebar-konten-positif/0/ siaran pers.

Bohang, K. F. (2017). Kominfo targetkan 2019 konten positif dominasi Internet Indonesia. Diakses 10 September 2017, dari https://tekno.kompas.com/ $\mathrm{read} / 2017 / 08 / 28 / 13294697 /$ Kominfotargetkan-2019-konten-positif-dominasi- 
internet-indonesia.

Buckingham, D. (2015). Defining digital literacy - what do young people need to know about digital media? Nordic Journal of Digital Literacy, 21-34.

CNN Indonesia. (2018). Blokir tak efektif, kominfo didesak buat aturan konten negatif. Diakses 10 Agustus 2018, dari https://Kominfo.cnnindonesia.com/ teknologi/20180710081813-192-312870/ blokir-tak-efektifKominfo-didesak-buataturan-konten-negatif.

Conway, C. (2014). The vlogger entrepreneurs. The International Journal of Entrepreneurship and Innovation, 15(4), 285-285.

Creswell, J. Kominfo. (2007). Qualitative enquiry and research design: Choosing among five approaches. Thousand Oaks, CA: Sage Publications.

Dale, K. R., Raney, A. A., Janicke, S. Kominfo., Sanders, M. S., \& Oliver, M. B. (2017). Youtube for good: A content analysis and examination of elicitors of self-transcendent media. Journal of Communication, 67(6).

detikINET. (2014). Ini penjelasan kominfo soal kisruh permen situs negatif. Diakses 1 Oktober 2018, dari https://inet.detik.com/ law-and-policy/d-2658940/ini-penjelasanKominfo-soal-kisruh-permen-situs-negatif.

Freischlad, N. (2017). Indonesia's digital economy will thrive as small businesses come online, says gov't. Diakses 10 Oktober 2018, dari https://Kominfo.techinasia.com/ indonesias-digital-economy-thrive-smallbusinesses-online-govt-plan.

Gilster, P. (1997). Digital Literacy. New York: Wiley.

Herman. (2017). "Kemudi" isi kekosongan literasi digital untuk anak muda. Diakses 4 Oktober 2018, dari https://Kominfo. beritasatu.com/iptek/409341-kemudi-isikekosongan-literasi-digital-untuk-anakmuda.html.

Hidayat, R. (2016). Mencari mekanisme pemblokiran yang tepat. Diakses 3 Oktober 2018, dari https://tirto.id/mencarimekanisme-pemblokiran-yang-tepat-b5tK

Huffington, A. (2015). What's working: All the news that's fit to print. Diakses 11 Januari 2018, dari https://Kominfo.huffingtonpost. com/arianna-huffington/whats-working- all-the-news b 6603924.html.

ICT Watch. (2014). Tanggapan ICT Watch atas RPM konten negatif. Diakses 2 Oktober 2018, dari https://Internetsehat.id/2014/03/ tanggapan-ict-watch-atas-rpm-kontennegatif/.

Jurriëns, E., \& Tapsell, R. (2017). Challenges and opportunities of the digital "revolution" in Indonesia. In E. Jurriëns \& R. Tapsell (Ed.), Digital Indonesia: Connectivity and Divergence (hal. 1-18). Singapore: ISEAS Publishing.

Kurnia, N., \& Astuti, I. S. (2017a). Researchers find Indonesia needs more digital literacy education. Diakses 10 September 2018, dari https://theconversation.com/ researchers-find-indonesia-needs-moredigital-literacy-education-84570.

Kurnia, N., \& Astuti, S. I. (2017b). Peta gerakan literasi digital di Indonesia: Studi tentang pelaku, ragam kegiatan, kelompok sasaran dan mitra. Informasi, 47(2), 149-166.

Kusuma, D. F., \& Sugandi, M. S. (2018). Strategi pemanfaatan Instagram sebagai media komunikasi pemasaran digital yang dilakukan oleh Dino Donuts. Jurnal Manajemen Komunikasi, 3(1).

Livingstone, S., van Couvering, E., \& Thumim, N. (2005). Adult media literacy: A review of the research literature. Diakses dari https://Kominfo.ofcom.org.uk/researchand-data/media-literacy-research/adults/ adult-media-literacy-review-2005.

Mahameruaji, N. J., Puspitasari, L., Rosfiantika, E., \& Rahmawan, D. (2018). Bisnis vlogging dalam industri media digital di Indonesia. Jurnal Imu Komunikasi, 15(1), 61-74.

Mendayun, I., \& Sjuchro, W. (2018). Efek komunikasi massa program Citizen Report di radio PRFM Bandung. Kajian Jurnalisme, 02, 98-114.

Murthy, D. (2012). Towards a sociological understanding of social media: Theorizing Twitter.Sociology,46(6),1059-1073.https:// doi.org/10.1177/0038038511422553.

Oliver, M. B., \& Raney, A. A. (2011). Entertainment as pleasurable and meaningful: identifying hedonic and eudaimonic motivations for entertainment consumption. Journal of Communication, 61(5), 984-1004. 
Poerwaningtias, I., Rianto, P., Ni'am, M., Adiputra, Kominfo. M., Marganingtyas, D., Mirasari, E., \& Misbah, A. N. (2013). Model-model gerakan literasi media dan pemantauan media di Indonesia. Yogyakarta. Yogyakarta: Pusat Kajian Media dan Budaya Populer.

Putri, R. D. (2018). Lezatnya kue iklan para influencer. Diakses 10 Januari 2019, dari https://tirto.id/lezatnya-kue-iklan-parainfluencer-cEVb.

Rahmawan, D., Mahameruaji, N. J., \& Hafiar, Kominfo. (2017). Peran vlogger sebagai online influencer dalam industri media digital di Indonesia. Promedia, 3(2), 183206.

Rahmawan, D., Mahameruaji, N. J., \& Janitra, A. P. (2018). Potensi Youtube sebagai media edukasi bagi anak muda. Edulib, 8(1), 81-98.

Rianto, P. (2013). Epilog: menimbang kontribusi literasi media bagi penguatan demokrasi. In I. Poerwaningtias, P. Rianto, M. Ni'am, Kominfo. M. Adiputra, D. Marganingtyas, E. Mirasari, \& A. N. Misbah (Ed.), ModelModel Gerakan Literasi Media dan Pemantauan Media di Indonesia (hal. 193206). Yogyakarta: Pusat Kajian Media dan Budaya Populer.

Rubin, A. M. (2009). The uses-and-gratifications perspective on media effects. In J. Bryant \& M. B. Oliver (Ed.), Media Effects: Advances in Theory and Research 3rd ed (hal. 165-184). New York, NY: Routledge. Ryssdal, K. (2014). No electricity in Indonesia, but there's Facebook. Diakses 1 Oktober 2018, dari https://Kominfo.marketplace. org/2014/07/02/tech/no-electricityindonesia-theres-facebook.

Saptya, R., Permana, M., Puspitasari, L., \& Indriani, S. S. (2018). Strategi promosi pada tahapan pra-produksi film 'Haji Asrama' (HAS). ProTVF, 2(2) 145-156. Diakses dari http://dx.doi.org/10.24198/ ptvf.v2i2.20818.

Semiocast. (2012). Twitter reaches half a billion accounts more than 140 millions in the U.S. Diakses 10 Juni 2017, dari https://semiocast. com/en/publications/2012_07_30_ Twitter_reaches_half_a_billion_ accounts $140 \mathrm{~m}$ in the US.

Vosoughi, S., Roy, D., \& Aral, S. (2018). The spread of true and false news online. Science, 359(6380).

We Are Social. (2018). Digital in 2018 in Southeast Asia. Diakses dari https:// Kominfo.slideshare.net/wearesocial/ digital-in-2018-in-southeast-asia-part-2southeast- 86866464 .

Wulandari, P. R. (2017). Indonesia perlu belajar mengatasi gagap digital dari Cina dan India. Diakses 6 Februari 2019, dari https:// theconversation.com/indonesia-perlubelajar-mengatasi-gagap-digital-dari-cinadan-india-85601.

Yosephine, L. (2017). Indonesia Instagram's biggest market in Asia Pacific. Diakses dari https://www.thejakartapost.com/ life/2017/07/26/indonesia-instagramsbiggest-market-in-asia-pacific.html. 